\title{
Implementation of ISO 9001:2015 in a Student Hostel: The Interested Parties' Perspective
}

Mohammed Fathy*, Mahmoud M. Hewedi, Azza Ali, Ayman Abdelhakim

Faculty of Tourism and Hotels, Fayoum University, Egypt

\section{ARTICLE INFO}

Keywords:

ISO 9001

Implementation

Students' hostels

Employees

Interested Parties

\begin{abstract}
ISO 9001 is a wide-implemented quality management system (QMS) standard. It was implemented in all sectors, including hospitality. However, previous research exposed the lack of research on ISO 9001 at institutional establishments, e.g., students' hostels. Thus, this study was conducted to bridge this gap in hospitality literature. This study explores the perspectives of interested parties- customers (students), employees and managers towards the implementation of ISO9001: 2015 at a student's hostel. Based on a constructive worldview, this study used an exploratory case study design. Multiple methods were used for collecting data from three groups of stakeholders', namely customers (students) $(n=334)$; employees $(\mathrm{n}=150)$ via self-administrative questionnaires and managers/ directors and supervisors $(\mathrm{n}=17)$ via structured interview. Sampling techniques included a random sample for students, surveying for employees, and purposive sampling for managers and supervisors. Quantitative data obtained from questionnaires were statistically analyzed using SPSS and qualitative data was thematically analyzed. The results revealed that the interested parties- customers (students) and employees have an important role in the implementation of ISO 9001. In addition, the qualitative analysis underlined the main perceived barriers and benefits for implementation of ISO 9001 at the students' hostel. One limitation of this study is the nature and design of the study which utilized case study. Thus, findings cannot be generalized for other institutions. This study is the first on students' hostels in developing context. It contributes to the literature by filling in the gap of ISO9001in welfare and non-profitable establishments. This may guide future research on this era in hospitality industry
\end{abstract}

C2021 Faculty of Tourism and Hotels, Fayoum University All rights reserved

\section{Introduction}

Today, universities are not only a researchable or educational base, but also a perfect life for students, particularly those who left their homes to study because they spend the majority of their time attending lectures, conducting research in libraries, or studying in student hostels. Imtiaz (2019) stated that a hostel offers lodging and food at fair prices to groups of students or persons. In hostels, a community of young men and women from diverse

\footnotetext{
*Contact Mohammed Fathy at: mfm03@fayoum.edu.eg
} 
backgrounds, both domestic and educational, are expected to absorb the attitudes and qualities needed to live together. Often, students learn from each other as much or more than from their instructors. Thus, by staying in the hostel, the educational reality can be realized in no small measure (Khan, et al, 2020).

The issues with the students' hostels have been underlined by many researchers in the literature. Adebisi et al. (2017) described a hostel as not a natural element of an action for learning in the educational sector but rather a support facility used to improve education efficiency, improve cleanliness, orderliness, security, and enhance student's performance and efficiency in learning. A hostel typically consists of shared facilities, such as a kitchen, toilet, reading room, guest hall, reception area, entertainment room, etc. Some universities provide such services to students inside the campus and some outside the campus.

The availability of university student hostels has been one of the core aspects that students and their parents are worried about when they enroll in a university. The importance of hostels as a major determinant of human well-being, sustenance, and survival cannot be overemphasized (Afolabi et al., 2019). It is, and will still be, a primary concern for individuals, families, and the environment. Students take into account the hostels before selecting the faculty they want to join, among other things (Ajayi, et al,. 2015).

In Egypt, Al-Azhar University in Cairo, Egypt, is a pioneering example of universities that have provided their students' residential facilities. Since its inception in $969 \mathrm{AD}$, it has offered its living-oncampus students a full educational system consisting of a theological and educational environment. At that moment, the students' hostels of thinking is that a university is in charge for the individual's overall preparation, including social and personal education, and must have student housing facilities (Hassanain, 2008).

Amer (2020) indicated in his study about "Evaluating Practices of University Student Hostels towards Meeting the Requirements of Sustainable Development" that this study examines the economic, social, and environmental practices of university student hostels to meet the requirements of sustainable development. Also, his findings exposed that awareness of management, leadership \& management participation willingness of employees, and finally the contribution of stakeholders, which were four factors, influenced sustainable development. Another study investigated the "mycological evaluation of serving some dairy products with special reference to mycotoxins production in Azhar University student hostels" (Khalifa, et al, 2013)

\subsection{Study Problem}

Service quality in the hospitality industry requires consistent delivery of services and products according to developing standards. One of the key challenges facing hospitality managers is providing quality service, as it is an imperative condition for success in the growing, competitive, international hospitality markets (Kapiki, 2012). To maintain a reasonable level of product and services quality, several standards (e.g., ISO), parameters, and criteria were developed and implemented through different ages.

While most studies on ISO 9001 have been undertaken in manufacturing or service industries; relatively few studies have been conducted on ISO 9001 in the hospitality industry. Between 2006 and 2021, at least, 12 studies were conducted to investigate the impact of ISO 9001 certification/implementation on hospitality organizations in different countries such as Spain, Portugal, Egypt, the Philippines, and Kenya. Most of the studies used questionnaires as a data collection tool, minority used document analysis or interviews and most of the sample were the employees. However, there is no in-depth study on ISO on students' hotels. Thus, this study is here to bridge this gap in hospitality literature. This study explores the roles and perspectives of interested parties- customers (students) and employees towards the implementation of ISO9001: 2015 at a student's hostel.

In Fayoum University in the academic year $1985 / 86$, cooperation was formed between the administration and the Fayoum governorate, provided that these students' hostels are subordinated to the university to provide all the services provided to students in other university hostels. This was accomplished as of December 1985, and since that year, students living in hostels have obtained both health and social care agreements and nutrition, equivalent to all other university hostels. With years, the building and facilities of the students' hotels were progressed and increased in Fayoum University. Recently, 
2005-2008 the female hostel was built in the West of the District of Eltaaweniat, which could accommodate 1,200 students. In the academic year 2007/2008, the University hostel B for female students was append in the West Eltaaweniat District, which was able to accommodate 1,200 students (Fayoum.edu.eg, 2020).Unfortunately, through time, students' hotels in Fayoum University faced many problems and challenges, including food poisoning of 100 female students in 2010 and same problem in 2008 (.youm7.com, 2020 ). Besides, the low quality of food service, accommodation, communication among students and staff as well as and malpractices of some members of supervisory staff were highlighted as main issues facing students' hotels (Hassanain, 2008).

The implantation of QMS should help in improving the products, service and hostels performance (e.g., Amer, 2020). Thus, although many studies were conducted in relating to different aspects of students' hostels, there is no in-depth study on the Implementation QMS in hostels in Egypt. Consequently, this study fills in the research gap related to students' hostels and ISO 9001: 2015 implementation.

\section{Literature Review}

\subsection{ISO 9001- quality management system}

The International Association for Standardization (ISO) issues thousands of standards annually. In 1987, ISO issued the ISO 9000 series of standards, including ISO 9001(Croft, 2012; Manders et al, 2016). Thousands of establishments in all sectors have implemented, got certified, and accredited based on ISO 9001 as the most widely applied quality management system (QMS). ISO 9001:2015 (the most up to date version of ISO 9001) outlines the requirements for implementing QMS and applies to any industry, regardless of the size or the location of establishment. It covers the infrastructure, procedures, processes, operations and resources required to assist establishments in controlling and improving their performance, as well as guiding them toward efficiency, customers' service, and product quality (Rybski, et al, 2017; Fonseca \& Domingues, 2018; Betlloch-Mas et al, 2019). In sum, the process of adopting a QMS is divided into various stages which concluding in the completion of an external audit, which, if passed, authorize the ISO 9001:2015 quality certification to be obtained and the organization to be certified (Betlloch-Mas, et al, 2019; Wolniak, 2019).

While most studies on ISO 9001 have been undertaken in manufacturing or services industries; relatively few studies have been conducted on ISO 9001 in the hospitality industry. Between 2006 and 2021, at least, 12 studies were conducted to investigate the impact of ISO 9001 certification/implementation on hospitality organizations in different countries such as Spain, Portugal, Egypt, the Philippines, and Kenya. Most of the studies used questionnaires as a data collection tool; minority used document analysis or interviews. Also, most of the sample was the employees. However, there is no in-depth study on ISO on students' hotels.

\subsection{Interested parties}

The ISO 9001:2008 standard was revised in September 2015. When compared to the version from 2008, there are numerous differences (Sari et al., 2017; Fouzi et al., 2021), including adding clause 4.2 which focusing on "relevant interested parties" (ISO, 2015). To be related, the interested party have to have some real or possible impact on the quality of the products and services (Fonseca, 2015). Establishments face a variety of challenges as a result of these changes such as customers' requirements (ISO, 2020). They generally deal with the structure of the standard, dealing with external and internal parties, process orientation, knowledge management, top management support and dealing with risks and opportunities. From now on, there will be a "High-Level Structure" that will apply to all future ISO management system standards, allowing for consistent handling and easier integration of various management systems (Abuhav, 2017).

An interested party is an individual or business that can involve, be affected by, or perceive themselves to be affected by a decision or activity that's related the scope of the QMS. There may also be requirements specified by internal interested parties, for example, management and staff (permanent and temporary). Typically these would include shareholders, owners, employees, trade unions, providers, management, partners, customer, government entities, media society, and any other individuals or establishments interested in the business or firm (Pretesh, 2019).

The needs and expectations of external and internal parties that have an impact on the establishment's 
QMS will be attentively examined (Wolniak, 2019). In addition, processes, including input and output, as well as process key figures, must be properly described. In addition, top management will be held more accountable for the efficacy of the QMS (Abuhav, 2017). There will be an increased demand for employees' competency development in knowledge management. Employee knowledge will be more strongly focused this way, and competency development will be thoroughly documented. Interested parties are more likely to trust establishments if they have an ISO certification. Furthermore, it motivates businesses to always develop to obtain certification (Rybski et al., 2017; Walaszczyk, 2018). The main interested parties are:

1. Customers: They are the most important interested parties who use the products and/or services of the establishment. They directly affect the ability of the organization by satisfying their needs by understanding their needs, expectations, and requirements.

2. Employees (Internal customers): Even though they are not purchasers of the establishment's products and/or services, they want to work in an environment that encourages them to fulfill the needs and expectations of the end customers.

3. Suppliers: They are the external providers those usually sign different kinds of contracts and approvals to supply and provide the needs, materials, and services' agreements, etc to the establishments. In addition, in many cases the organizations and suppliers may have to be implemented and certified based on QMS.

4. Government and non-government establishments: Many sectors in hospitality industry, including students' hostels must meet the legal requirements and operational procedures that prove that their products and services meet such legal requirements. For example, the quality and safety of provided meals for students as well as the accommodation and study areas requirements.

In the case of the hostel as an institutional system made up of several actors and interested parties with various functions and areas of responsibility who work independently to enable the hostel to achieve its goals and carry out its functions in the most efficient way possible while maintaining a high level of service quality(Abuhav, 2017; Fouzi et al., 2021). The interested parties investigated in this study are students (customers), employees, and managers.

2.3 The roles of interested parties in ISO implementations

To be certified by ISO 9001: 2015 standard; hereby, the organization must meet the needs of interested parties to enhance the establishment performance; it must also analyze the conversation with numerous actors who have well-defined goals and expectations (Rybski et al., 2017; Fouzi et al., 2021). According to, ISO9001:2015 requirements, the organization or establishment considers only the interested parties which have been determined to be relevant to its QMS. In this regard, Pretesh (2019) mentioned that the establishment can make a decision to determine additional needs and expectations that will assist in meeting its quality objectives. However, it is at the firm's discretion whether or not to accept other requirements to satisfy interested parties beyond what is required by QMS.

In addition, the requirements are to determine what interested parties are relevant to the QMS, and the requirements of these parties that can affect the QMS. Due to the roles and effects of interested parties on the QMS implementation and certification, so it is significant to collect all the information that is needed for the QMS implementation. This is also fundamental for shaping who is a relevant interested party for the implemented QMS, including customers (students in this case), employees and top management (Hammar, 2021). The role(s) of each interested party is determined by the establishment and specifically the quality assurance unit based on the ISO 9001:2015 clauses. The roles of all interested parties must be integrated to meet the requirements of the QMS. This should facilitate the internal and external audits and positively influence the establishment performance.

ISO 9001 is the world best-known and most popular quality management standard, is to be implemented quickly with minimal investment. there is 5-step to get certified (9001Simplified, 2021):

Step 1: is preparing a small or medium-sized organization to achieve ISO 9001 certification - including deciding on the implementation plan. It provides the basis for the operation as a critical phase and has an impact on the ISO system's long-term success. 
Step 2: Documentation writing is frequently regarded as the hardest phase in implementing it. Documents must satisfy the technical standards of ISO 9001 which certain people find difficult to comprehend, interpret, and apply for their enterprise.

Step 3: Implementation: during the implementation process, the persons concerned will introduce procedures and be able to change their work processes and improve them properly. In some ways, the implementation of ISO 9001 demands nearly all staff to adapt their method of working (for example, how they use documents). The benefits of change and efficient, non-bureaucratic, and userfriendliness of new processes must be visible to the success of ISO.

Step 4: Internal audits are self-inspections for the effectiveness of the ISO 9001 system. They are performed before and periodically thereafter certification is achieved. Internal audits are conducted by staff who has received auditors' training; however, they may want to be externalized. The aim is to ensure that ISO 9001 is complied with, as are processes and working instructions.

Step 5: Certification after a completed audit performed by an impartial third-party auditor, the organization receives ISO 9001 certification. This audit can be carried out on location or remotely.

\subsection{Benefits of \& Barriers to ISO 9001 Certification}

Perceived motivations and benefits of ISO 9001 implementation and certification can be divided into two levels: internal and external motivations. Internal motivations are associated to attain organizational improvement, whereas external motivations are mostly associated with promotional and marketing motivations, customer pressures, and market share improvement (Sampaio et al., 2009). Similarly, Tarí et al. (2012) extract that the benefits of ISO 9001 can be divided into two categories: internal and external, including, people-related, operational, customer, and financial benefits, which might then be classified as internal or external. Internal benefits include improvements to organizational processes that have a positive impact on operational and people management issues (e.g. increase in productivity, improvement in efficiency and reduction in costs and waste, training). External benefits are those that have an impact on customers and society as a whole (e.g. customer satisfaction, better relationships with stakeholders, improved image) (Wilcock \& Boys, 2017; Fonseca \& Domingues, 2018).

The most important reasons for certification given by Egyptian organizations: "improve the efficiency of the quality system," "pressures from competitors/foreign partners," "maintain/increase market share," "meet government demands," and "comply with consumer requirements." Some organizations also indicated that without ISO 9001 certification, they would be unable to secure a large number of contracts (Magd \& Curry, 2003; Sampaio et al., 2009).

Additionally, Lourenço \& Fonseca (2012) stated that the most important motivations were organization image and customer pressure; the most important perceived benefits are customer satisfaction, better organization image, and better relations and communications with customers; there is a significant relationship between internal motivations and internal benefits; there is a positive relationship between QMS certification and organizational performance motivation.

Conversely, the implementation of ISO 9001is facing many barriers worldwide. When the decision to implement is made, there are different barriers to be overcome. Certification does not ensure a smooth QMS deployment as the process brings about the organization's unavoidable changes. Many forces against it present obstacles, for example, change resistance barriers, low departmental interdependence, lack of top management commitment, bureaucratic dominance, lack of internal communication between employees and between employees and the management, Inadequate communication of needs at all levels of an organization, lacking training, change of culture, process identification and management difficulties (Bounabri et al, 2018).

\section{Methodology}

The study adopted case study methodology as its design to achieve this study purpose. The researchers believed that a case study would enable them to understand the relationship between the effects of basic principles of ISO 9001 and improve Fayoum University hostel performance for girls. 
A case study is a "research method involving an up-close, in-depth, and detailed examination of a particular case" (Bhatta, 2018). Woodside, (2010) also defined a case study as "an empirical inquiry that investigates a contemporary phenomenon within its real-life context, especially when the boundaries between phenomenon and context are not evident".

The case study strategy is dealt with researching a unit of study (A single case study) or more than one unite (multiple case studies) (Robson \& Mccartan, 2016). Furthermore, the case study strategy is unique because it contributes to a particular kind of knowledge related to other strategies (Yin, 2004). One of the main disadvantages of a case study is that the data collected cannot necessarily be generalized to the wider population. Also, some of the case studies are not scientific and Case studies are generally performed on one person, but they also tend to be a single data-gathering experimenter. This can lead to bias in the collection of data, which can influence results more than in different designs. Furthermore, it is also very difficult to draw a definite cause/effect from case studies (Bhatta, 2018).

The design also appeals to social researchers, even as critics doubt the integrity of case studies. Case studies are rich in data, qualitative, and include a range of evidence sources. Design proponents are laborious to evaluate too many qualitative results. Data triangulation is, however, generally considered to increase the credibility of case studies. If researchers only obtain a single source of data, it is recommended that they should choose different design elements (Smith, 2018).

Based on previous studies, including Bounabri et al.( 2018); Lourenço \& Fonseca (2012); expectations (Rybski et al., 2017), three methods were used for collecting data; self-administrative questionnaires (one for students and the other for employees), and structured interviews for managers. In addition, the structured interviews used a structured- interview schedule based on a predetermined and standardized or identical set of questions (Lourenço \& Fonseca 2012).

In this study three groups of stakeholders were investigated; customers (students) $(n=334)$; employees $(n=150)$ and managers/ directors and supervisors $(n=17)$. Sampling techniques included a random sample for students $(\mathrm{N}=1800)$ and survey for employees $(\mathrm{N}=150)$, and purposive sampling for managers and supervisors $(\mathrm{N}=17)$. Quantitative data obtained from questionnaires were statistically analyzed using SPSS, 23. Qualitative data were manually thematically analyzed. For the reliability statistics of the questionnaire of students Cranach's Alpha was accepted (.83) and for staff questionnaire was (.87). In the case of interview, 17 interviews achieved the saturating level of data.

\section{Results and Discussion}

\subsection{Employees' perspectives of ISO Implementation}

The main aim of questioning the employees was to identify their roles and perspectives towards the steps of ISO implementing at their student hostel. The analysis showed that the response rate of employees' rate was $75.33 \%$ (113/150), which is a relatively accepted rate. The findings revealed that nearly everyone of employees (99.1\%) working at the implementation students' hostels were aware that the employee's perspective towards the steps, efforts of the students' hostels for implementing and get certified according to the standards of ISO 9001:2015.

In sequence to the awareness of the process, table (1) illustrate that employees' opinion towards the involvement in the implementing and certification process, where $88.5 \%$ of employees engaged in the certification process, and $11.5 \%$ did not participate. These findings may be due to the nature of work of some employees. However, for implementing QMS, all types and levels of staff member should be involved, not only the quality assurance team. The results indicate that $30.1 \%$ of the employees had been involved in concentrate on nonconfirmative points identified during the internal and external audits; while $15.9 \%$ of them had been involved in sensitization/ Awareness. Also, 13.3\% had been involved in Auditing, 12.4\% had been involved in coordination, 9.7 had been involved in documentation, and only $7.1 \%$ had been involved in Decision making.

Table 1

Participation of employees in ISO9001:2015 implementation

\begin{tabular}{|c|c|c|c|}
\hline \multirow{2}{*}{\multicolumn{2}{|c|}{ Variables }} & \multicolumn{2}{|c|}{ Total } \\
\hline & & \multirow{2}{*}{$\begin{array}{c}\mathbf{F} . \\
100\end{array}$} & \multirow{2}{*}{$\begin{array}{c}\% \\
88.5 \\
\end{array}$} \\
\hline Participation in & Yes & & \\
\hline the certification & No & 13 & 11.5 \\
\hline process? & Total & 113 & 100 \\
\hline \multirow{3}{*}{$\begin{array}{l}\text { Ways of } \\
\text { participation in } \\
\text { ISO9001:2015 }\end{array}$} & Decision making & 8 & 7.1 \\
\hline & Documentation & 11 & 9.7 \\
\hline & Coordination & 14 & 12.4 \\
\hline
\end{tabular}




\begin{tabular}{|c|c|c|c|}
\hline \multirow{4}{*}{$\begin{array}{l}\text { implementation } \\
\text { process }\end{array}$} & Awareness & 18 & 15.9 \\
\hline & Auditing & 15 & 13.3 \\
\hline & $\begin{array}{l}\text { Addressing } \\
\text { Nonconformities }\end{array}$ & 34 & 30.1 \\
\hline & Total & 113 & 100.0 \\
\hline \multirow{4}{*}{$\begin{array}{l}\text { Duration of } \\
\text { participation in } \\
\text { ISO9001:2015 } \\
\text { implementation } \\
\text { process }\end{array}$} & a year & 76 & 67.3 \\
\hline & $\begin{array}{l}\text { More than one } \\
\text { year }\end{array}$ & 15 & 13.2 \\
\hline & 2-3years & 9 & 8 \\
\hline & Total & 113 & 100 \\
\hline
\end{tabular}

In addition, nearly $89 \%$ of the employees indicated that they had been involved in the ISO 9001 implementation process in one way or the other, with the period of involvement varying from less than one year to over three years. Although 67.3\% of employees had been involved in the process for one year, $13.2 \%$ had been involved for more than one year, and only $8 \%$ had been involved for 2 to 3 years.

Table (2) shows that the employees' opinion towards the certification process is varied. As can be seen in table (2), $41.6 \%$ of the employees agree that the administration's commitment to ISO certification was evident; $40.7 \%$ were neutral with it, $9.7 \%$ were strongly agreed, and $4.4 \%$ and, $3.5 \%$ were strongly disagree, disagree with the statement. The table also shows that the employees' opinion towards the establishment's appointment of an external consultant to assist in obtaining certification $96.5 \%$ of the employees agreed that the students' hostel had used an external consultant to help, and $3.4 \%$ of them did not agree.

Table 2

opinion of employees towards Certification Process

\begin{tabular}{|l|l|c|c|}
\hline \multicolumn{2}{|c|}{ Variables } & \multicolumn{2}{c|}{ Total } \\
\cline { 2 - 4 } & F. & $\%$ \\
\hline $\begin{array}{l}\text { Administration's } \\
\text { commitment to ISO } \\
\text { certification }\end{array}$ & $\begin{array}{l}\text { Strongly } \\
\text { Disagree }\end{array}$ & 5 & 4.4 \\
\cline { 2 - 4 } & Disagree & 4 & 3.5 \\
\hline
\end{tabular}

Table (3):

\begin{tabular}{|l|l|c|c|}
\hline \multirow{5}{*}{\begin{tabular}{|l|c|} 
External consultant \\
participating in \\
certification process
\end{tabular}} & Neutral & 46 & 40.7 \\
\cline { 2 - 4 } & Agree & 47 & 41.6 \\
\cline { 2 - 4 } & Strongly agree & 11 & 9.7 \\
\cline { 2 - 4 } & Total & $\mathbf{1 1 3}$ & $\mathbf{1 0 0}$ \\
\cline { 2 - 4 } & No & 109 & 96.5 \\
\hline \multirow{4}{*}{$\begin{array}{l}\text { Extent of assistance } \\
\text { provided by the } \\
\text { consultant in } \\
\text { certification process. }\end{array}$} & Do not know & 4 & 3.6 \\
\cline { 2 - 4 } & Serall extent & 6 & 5.3 \\
\cline { 2 - 4 } & Average extent & 16 & 14.2 \\
\cline { 2 - 4 } & Large Extent & 30 & 26.5 \\
\cline { 2 - 4 } & extent & 51 & 45.2 \\
\cline { 2 - 4 } & Total & $\mathbf{1 1 3}$ & $\mathbf{1 0 0}$ \\
\hline
\end{tabular}

There is $45.2 \%$ of employees believe that the external consultant has contributed to a huge extent to the certification process. In contrast, $26.5 \%$ has contributed a large extent to the operation, but 14.2 $\%$ say that the consultant has contributed by average extent to the process and $5.3 \%$ of them were not sure of participation.

This part shows in tables ( 3 ) that most of the employees were have an awareness of ISO certification and are involved in the implementation process and this is consistent with (Mutinda,2012) when he pointed out that they should be given awareness training programs in place to ensure that employees at each significant function and level are aware of the practice, quality programs, and procedures of the ISO 9001 systems. An intensive system needs to be provided, especially in the fields of problem identification and having techniques. Also agreed with (Tsim, Yeung, \& Leung, 2002), which showed that gaps in work should be identified and strategies for effective employment systems, which are the primary step for the continuous improvement process

Results of the employees towards the degree of implantation of QMS

\begin{tabular}{|l|c|c|c|c|c|c|c|}
\hline Variable & $\begin{array}{l}\text { Do not } \\
\text { know } \\
\text { very }\end{array}$ & $\begin{array}{c}\text { Small } \\
\text { degree }\end{array}$ & $\begin{array}{c}\text { Moderate } \\
\text { degree }\end{array}$ & $\begin{array}{c}\text { Large } \\
\text { degree }\end{array}$ & $\begin{array}{l}\text { Very large } \\
\text { degree }\end{array}$ & Mean & $\begin{array}{l}\text { Std. } \\
\text { Deviation }\end{array}$ \\
\hline $\begin{array}{l}\text { Adequate awareness creation of staff on } \\
\text { the benefits of ISO 9001 certification was } \\
\text { conducted. }\end{array}$ & 10.6 & 5.3 & 48.7 & 26.5 & 8.8 & 3.18 & 1.037 \\
\hline $\begin{array}{l}\text { An ISO certification plan of action was } \\
\text { communicated to staff adequately. }\end{array}$ & 4.4 & 4.4 & 32.7 & 60 & 6 & 3.50 & 0.846 \\
\hline $\begin{array}{l}\text { The commitment of top management was } \\
\text { evident to everyone in the hostel. }\end{array}$ & 8 & 4.4 & 35.4 & 33.6 & 18.6 & 3.50 & 1.095 \\
\hline $\begin{array}{l}\text { A pre-assessment audit (gap analysis) was } \\
\text { conducted. }\end{array}$ & 6.2 & $2 . .7$ & 23.9 & 47.8 & 19.5 & 3.72 & 1.013 \\
\hline
\end{tabular}


M. Fathy et al. / IJHTH vol 15 issue 1 (2021) 38-50

\begin{tabular}{|l|c|c|c|c|c|c|c|}
\hline $\begin{array}{l}\text { A Quality Manual and Quality policy } \\
\text { statement was prepared }\end{array}$ & 1.8 & 8.8 & 42.5 & 25.7 & 21.3 & 4.00 & 4.937 \\
\hline $\begin{array}{l}\text { Standard Operating Procedures (SOPs) } \\
\text { for key processes were in place. }\end{array}$ & 8.8 & 8 & 27.4 & 40.7 & 15 & 3.45 & 1.118 \\
\hline $\begin{array}{l}\text { New SOPs for critical processes were } \\
\text { prepared }\end{array}$ & 8 & 14.2 & 46.9 & 24.8 & 6.2 & 3.07 & 0.979 \\
\hline $\begin{array}{l}\text { Management reviews were held at a } \\
\text { planned interval. }\end{array}$ & 8 & 11.5 & 24.8 & 43.4 & 12.4 & 3.41 & 1.099 \\
\hline Internal audits were conducted as planned. & 4.4 & 8.8 & 38.1 & 20.4 & 28.3 & 3.59 & 1.123 \\
\hline $\begin{array}{l}\text { Appointment of ISO Coordinators and } \\
\text { team. }\end{array}$ & 6.2 & 2.7 & 37.2 & 38.1 & 22.1 & 3.55 & 1.000 \\
\hline $\begin{array}{l}\text { External audits were conducted as } \\
\text { planned. }\end{array}$ & 6.2 & 6.2 & 26.5 & 34.5 & 26.5 & 3.60 & 1.106 \\
\hline $\begin{array}{l}\text { Adequate time was given for the } \\
\text { implementation of the QMS. }\end{array}$ & 3.5 & 7.1 & 46.9 & 23.9 & 18.6 & 3.69 & 1.119 \\
\hline $\begin{array}{l}\text { Funds were available to facilitate the } \\
\text { implementation of the QMS. }\end{array}$ & 8.8 & 10.6 & 31.9 & 40.7 & 8 & 3.47 & .992 \\
\hline $\begin{array}{l}\text { The sequence and interaction of key } \\
\text { processes in the hostels were determined, } \\
\text { e.g., flow charts, etc. }\end{array}$ & 4.4 & 5.3 & 32.7 & 33.6 & 23.9 & 3.28 & 1.056 \\
\hline Mean & & & 3.5 & & \\
\hline
\end{tabular}

The overall average value (3) shows a moderate degree of the respondent on the element of the degree of application of the quality management system also the standard deviation values that less than half of the Mean value conforms the agreement of the respondent in their choices.

The degree of application of the quality management system is one of the indicators that Measure the Effect of ISO implementation on hostel's performance from the employees' point of view. They have a neutral opinion on the 14 statements that Measure the Effect of ISO implementation on hostel's performance.

As can be seen in table (3), employees have a moderate degree of the respondent with the statement". Adequate awareness creation and sensitization of staff on the benefits of ISO 9001 certification conducted" (Mean=3.18). Also, they have a large degree opinion with the statements" an ISO certification plan of action was communicated to staff adequately" and "the commitment of top management was evident to everyone in the hostel" (Mean= 3.50)". A pre-assessment audit (gap analysis) was conducted" was another statement that the students with large degree opinion with a Mean value (Mean=3.72)". A Quality Manual and Quality policy statement was prepared" was another statement that the employees with Substantial degree giving a comparatively high Mean value (Mean=4.00). Besides, they have a large degree to the statement" Standard Operating Procedures (SOPs) for key processes were in place" $($ Mean=3.60).
"SOPs for critical processes were prepared" was another statement that the employees with moderated degrees giving a comparatively high Mean value (Mean=3.07). Also, they have moderated the degree to the statement "Management reviews were held at a planned interval" (Mean=3.41) They have a large degree to the statement" Internal audits were conducted as planned" (Mean=3.59). Besides, they have a large degree to the statement "Appointment of ISO champions (Coordinators)" (Mean=3.55)". External audits were conducted as planned" was another statement that the employees with a considerable degree, giving a comparatively high Mean value (Mean=3.60). Besides, they have a large degree to the statement" Adequate time was given for implementing the Quality Management System" (Mean=3.69). They have moderated the degree to the statement." Funds were available to facilitate the implementation of the Quality Management System" (Mean=3.47) Besides, they have moderated degree to the statement" The sequence and interaction of key processes in the institute were determined, e.g., flow charts, etc." $($ Mean=3.28)

From the results shown in table (3) the principles as pulling out of achieving the ISO certification have been achieved, such as awareness, gap analysis, and management's responsibility to getting the certification. Furthermore, that is agreed with for an institution to carry out the significance of achieving quality processes, and it must know capable of bolstering the implementation process. 
(Mutinda,2012) Also agreed with (Tsim, Yeung, \& Leung, 2002), which showed that gaps in work should be identified and strategies for effective employment systems, which are the primary step for the continuous improvement process. Also (Tomic \& Spasojevic Brkic, 2019) mentions that he has found internal audit as the most significant to continual improvement ISO 9001 requirement, along with marginally fewer significant corrective actions.

Table (4):
4.2. Students' perspectives towards the Implementation and certification of the ISO 9001: 2015

The table shows that the grand mean value is 3.07 , which indicates a 'neutral 'perception of the students towards Implementation and certification of the ISO 9001: 2015 system in the University hostel for Female Students in Fayoum.

Students' perspectives towards the implementation of the ISO 9001: 2015

\begin{tabular}{|l|l|l|l|l|l|l|l|}
\hline Variable & 1 & 2 & 3 & 4 & 5 & Mean & $\begin{array}{l}\text { Std. } \\
\text { Deviation }\end{array}$ \\
\hline $\begin{array}{l}\text { Level of acceptance of ISO 9001:2015 } \\
\text { implementation }\end{array}$ & 8.5 & 15.6 & 27.0 & 41.2 & 7.6 & 3.24 & 1.078 \\
\hline $\begin{array}{l}\text { Level of suitability of ISO 9001:2015 } \\
\text { implementation }\end{array}$ & 18.0 & 21.8 & 28.4 & 26.5 & 5.2 & 2.79 & 1.173 \\
\hline $\begin{array}{l}\text { Level of priority of ISO 9001:2015 } \\
\text { implementation }\end{array}$ & 10.4 & 16.1 & 30.8 & 30.3 & 12.3 & 3.19 & 1.201 \\
\hline $\begin{array}{l}\text { Level of importance of ISO 9001:2015 } \\
\text { implementation }\end{array}$ & 7.6 & 19.9 & 36.5 & 28.4 & 7.6 & 3.09 & 1.043 \\
\hline $\begin{array}{l}\text { Level of acceptance of ISO 9001:2015 } \\
\text { implementation }\end{array}$ & 8.5 & 15.6 & 27.0 & 41.2 & 7.6 & 3.24 & 1.078 \\
\hline \multicolumn{7}{|c|}{ Mean } & \multicolumn{7}{|c|}{$\mathbf{3 . 0 7}$} & & \\
\hline
\end{tabular}

As can be seen in the table (4), students have a neutral acceptable with the statement" Implementation and certification of the ISO 9001: 2015 system in the University hostel for Female Students in Fayoum" (Mean= 3.24). Also, they have unbiased priority to the statement," Implementation and certification of the ISO 9001: 2015 system in the University hostel for Female Students in Fayoum." (Mean= 3.19)." Implementation and certification of the ISO 9001: 2015 system in the University hostel for Female Students in Fayoum" was another statement that the students with, neutral important (Mean=3.09). Also, they have an unbiased appropriate with the statement." Implementation and certification of the ISO 9001: 2015 system in the University hostel for Female Students in Fayoum." (Mean= 2.79).

\subsection{Managers' interview Analysis}

The aim of conducting the interview with managers was to find out their point of views on the implementation and certification of ISO 9001:2015 at their hostels. The number of interviews $(n=17)$ was enough to achieve saturating level. The interview data was thematically analyzed. The main themes and evident are presents in the fellow.

\subsubsection{Starting the ISO certification process}

When interviewees were asked about the start of preparing to apply ISO 9001:2015, they provided various starting dates. Based on their replies, they can be categorized into three groups. The first group included most of the interviewees $(n=8)$ and agreed that the starting data for ISO procedures was in July 2017 such as (YWD, SAS, FSH1, and FSH2) ADQAU stated, "The first idea to obtain the ISO certification was in July 2017 with the beginning of the establishment of the unit" correspondingly. The second group included five interviewees and agreed that they started in March 2017. This is clear in what was mentioned by the director of the quality assurance unit (DQAU): "It can have been said that the rehabilitation began after establishing the quality unit in March 2017 after the unit's regulations were approved" Finally, only an interviewee mentioned that the procedures started in November 2017.

\subsubsection{Reasons for implementing ISO 9001}

When interviewees were asked about the reasons for obtaining the ISO certificate ISO 9001:2015, they provided several reasons. Based on their 
replies, they can be categorized into several reasons. It was evident that most of the interviewees agreed that the reason is to develop the establishment performance and there are further reasons such as, developing training and qualifying employees, having consolidated a goal establish a consolidated system to work in all departments, improving the quality of provided services, customer's satisfaction, and loyalty to the establishment (Students hostels). PD stated, "The reason is to improve the establishment performance, qualifying employees and Establish a centralized system to use in all departments," likewise a student activities supervisor (SAS) stated that "Work with a stable and consolidated system in the establishment which it can measure the level of service provided and not be affected by the absence of a member of the establishment and can be developed and improve the service". Moreover, improving establishment performance is affected by these reasons.

4.3.3. Reason for selected this establishment specifically for accreditation

Interviewees were questioned about the reason for specifically selected this establishment for accreditation with the Quality Management System 9001: 2015. They provided two significant reasons; the most refer that to the capability of the infrastructure of the establishment $(\mathrm{N}=10)$ DQAU stated that: "The reason for specifically selected this establishment for accreditation with the Quality Management System 9001: 2015 in this time the infrastructure of the establishment accreditation for stated up a quality system"

The minority they provided the reason for the desire of employees for development they provide services ( $\mathrm{n}=6$ ) Nutrition Director stated that "The reason for selected this establishment for accreditation with the Quality Management System 9001: 2015 The desire of employees for development they provide services for students."

\subsubsection{Awareness provided to the employees about} acquiring the ISO

In this particular question, all of the interviewees, with one accord $(n=17)$, agreed that the establishment provided them with appropriate awareness through many means such as meetings, workshops, debates, and symposiums. That was through Consultation Company and Quality Assurance Unit; GDUC stated, "Several meetings, workshops, debates, and symposiums have been conducted through Consultation Company and Quality Assurance Unit." Also, this is clear in what was mentioned by Youth Welfare Director "Awareness was provided to employees within the establishment through workshops on quality and its importance through specialized from consultation company and Quality Assurance Unit."

\subsubsection{Training and awareness methods}

They provided the privies question that the establishment provided them with appropriate awareness through many means, such as meetings, workshops, debates, and symposiums. And resumption it questioned Interviewees about the training and awareness methods that have been provided in the establishment for accreditation with the Quality Management System 9001: 2015. Most of the Interviewees stated that they have an awareness of ISO certification, its importance, policies, goals, principles $(\mathrm{n}=7)$; also, a workshop had held on safety rules and basics $(n=6)$ and Internal audit $(\mathrm{n}=4)$. Such as Youth Welfare Director stated, "There was a workshop on ISO certification, its importance, policies, goals, principles. And other about safety rules and basics and Internal audit know how auditing each department." and the minority stated that they had given awareness, but they did not mention awareness methods $(n=3)$.

\subsubsection{Employee's opinion about the reaction to starting the ISO}

In this condition, we have three opinions, the first opinion that the employees' Opposition at first $(n=8)$, but then everyone accepted it, and that agreed with what NSH2 stated that: "There was opposition from some employees, but they were quickly convinced of it, as they were convinced of its importance." The second opinion that everyone from the start acceptable for the certification process $(n=6)$, and that agreed with what HS1 stated, "The topic was acceptable by everyone to improve the level of service and the existence of a system to be relied upon". The third opinion was stated that the responses were different from employee to others $(n=2)$ and that concur with what AD stated that: "In the beginning, there was a different opinion from employee to another between a supporter and an opponent, but with awareness, continuity and goal setting, all was agreed."

4.3.7 Acceptance level of the accreditation process. 
When interviewees were questioned concerning the evidence Which indicates the acceptance of employees of the establishment accepts the accreditation process to obtain the ISO certificate they provide much defiant evidence, the majority stated that most evidence Which indicates the acceptance of employees was full interest in work and sufficient effort, working through an integrated work team and active participation in the accreditation process $(n=10)$. And minority view that the evidence which indicates the acceptance of employees was obtained the ISO certificate $(n=7)$.

\section{Conclusion, implications, and future research}

ISO 9001 is a quality management standard that many establishments widely adopt; the study aims to analyze the Interested Parties' Perspectives in processes of implementation of ISO 9001:2015 in Student's Hostel. Similar to the findings of the study that indicated to all of the interested parties have different perspectives. All parties play a role in the processes of implementation, and all parties benefit from the accreditation process. Students are the primary beneficiaries of the accreditation process as they are the main target of the process, through the development and improvement processes for all the services provided, as well as the participation of their representatives in the accreditation process and design questionnaires by the customers' service department and evaluate those services and continuous development. Employees benefit from the existence of a clear goal for everyone that can be achieved and worked through it, which defines the tasks and responsibilities of everyone in the organization. Finally, based on these ideas, research proposals for future research regarding the interested parties' perspectives can be suggested. Future studies could analyze the effects of the role of other interested parties perspectives in processes of Implementation of ISO 9001:2015 in Student Hostel such as suppliers' and governments \& nongovernment organizations.

The findings of this study may be used as guide for other students' hostels at Fayoum University, for instance the male students' hostels to be certified. In addition, the implantation and accreditation help the administrative teams of the students' hostels to control and improve many procedures, which facilitate and improved the products and service. As well as positively influenced the students and staff satisfaction by creating a positive work environment.

Similar to other studies, this study has some limitations which may guide the future research. Firstly, this study adopted an exploratory case study methodology. Future research may consider other students hostel based on a quantitative crosssectional design. Secondly, this study focused on female students' hostels and measured their perspectives. Future studies may compare between male and female students' perspectives to the impact of ISO 9001:2015 implementation on the quality of products and services. Finally, this study focused on an institutional sector (students' hostels) of the hospitality industry, further studies may study ISO implementation and certification in other commercial establishments of the hospitality industry, including hotels, private hospitals, and restaurants.

\section{References}

9001Simplified (2021). How to get ISO 9001 Certification Step-by-Step Guide. Retrieved on 6/6/2021, from: https://www.9001 simplified.com/learn/iso-9001certification-steps.php.

Abuhav, I. (2017). ISO 9001: 2015-A complete guide to quality management systems. CRC press.

Adebisi, O. S., Oletubo, A. A., Alade, T. J., \& Aghogho, E. (2017). Perspectives of Students on Private Hostel Facilities in Proximity to the Federal University of Technolgy, Akure, Nigeria. Perspectives, 33, 31-36.

Afolabi, T. O., Ajibola, M. O., \& Oluwunmi, A. O. (2019). An investigation of the factors motivating students' stay in private universities' hostels. Covenant Journal in the Research Built Environment, 7(2), 1-8.

Ajayi, M., Nwosu, A. and Ajani, Y. (2015). Students' satisfaction with hostel facilities in federal university of technology, Akure, Nigeria. European Scientific Journal, 11(34), 402-415.

Amer, T. (2020). Evaluating practices of university student hostels towards meeting the requirements of sustainable development. Journal of the Faculty of Tourism and Hotels-University of Sadat City, 4.1/1 72- 95.

Betlloch-Mas, I., Ramón-Sapena, R., Abellán-García, C., \& Pascual-Ramírez, J. C. (2019). Implementation and operation of an integrated quality management system in accordance with ISO 9001: 2015 in a dermatology department. Actas Dermo-Sifiliográficas (English Edition), 110(2), 92-101.

Bhatta, T. P. (2018). Case study research, philosophical position and theory building: a methodological 
discussion. Dhaulagiri Journal of Sociology and Anthropology, 12, 72-79.

Bounabri, N., El Oumri, A. A., Saad, E., Zerrouk, L., \& Ibnlfassi, A. (2018). Barriers to ISO 9001 implementation in Moroccan organizations: Empirical study. Journal of Industrial Engineering and Management (JIEM), 11(1), 34-56.

Croft, N.H. (2012). ISO 9001:2015 and beyond Preparing for the next 25 years of quality management standards. ISO Focus 36 . Retrieved on 15/07/2021 from: http://www.iso.org/iso/news.htm?refid=Ref1633.

Fayoum.edu.eg/. (2020). Fayoum hostels. Retrieved on 15/04/2020, from http://www.fayoum.edu.eg/

Fonseca, L. M. (2014). ISO 9001: 2015 Revision. Paper presented at the 1st International Conference on Quality Engineering and Management, UK.

Fonseca, L. M., \& Domingues, J. P. (2018). Empirical research of the ISO 9001: 2015 transition process in Portugal: motivations, benefits, and success factors. Quality Innovation Prosperity, 22(2), 1645.

Fouzi, B., El Idrissi, H., \& Nouzha, J. (2021). Applying a risk management approach in controlling QMS processes and interactions with the relevant interested parties: The case of an airport. Iraqi Journal of Science, 67, 36-43.

Hammar, M. (2021). ISO 9001:2015 interested parties How they are determined. Advisera Expert Solutions Ltd. Retrieved on 11/07/2021, from https://advisera.com/9001academy/blog/2015/11/1 0/how-to-determine-interested-parties-and-theirrequirements-according-to-iso-90012015

Hassanain, M.A. (2008). On the performance evaluation of sustainable student housing facilities. Journal of Facilities Management, 6(3) 212-225.

Imtiaz, K. S. (2019). Effect of quality service provision on student satisfaction by private hostels in Kenya. A case of hostels around USIU-Africa, Nairobi. (MSc), United States International UniversityAfrica.

ISO, I. O. for S. (2015). International Standard for QMS ISO 9001:2015. International Organization for Standardization (ISO). Retrieved on: 12/03/2020, from: https://www.iso.org/standard/62085.html

ISO. (2020). ISO Survey of certifications to management system standards - Full results. retrieved on 15/04/2020, from https://www.quality.org/news/iso-survey-2019management-system-standard-certifications

Kapiki, S. (2012). Quality management in tourism and hospitality: An exploratory study among tourism stakeholders. International Journal of Economic Practices and Theories, 2(2), 53-61.

Khalifa, M. I., Al-Ashmawy, M. A., Abdel-Khalik, A., \& El-Sherbini, M. (2013). Mycological evaluation of serving some dairy products with special reference to mycotoxins production in Azhar University student hostels. World Journal of Dairy \& Food Sciences, 8(2), 165-170.

Khan, F. R., Shekili, A., Said, N., Al Badi, A. S., \& Al Khanbashi, H. A. (2020). Exploring the impact of hostel life of students on academic performance: Sohar University-a case study. International Journal of Research in Entrepreneurship \& Business Studies, 1(1), 1-14.

Lourenço, L., Fonseca, L., \& Mendes, L. (2012). ISO 9001 certification: Motivations, benefits and impact on organizational performance. Paper presented at the 3rd Annual European Decision Sciences Institute Conference- June 24-27, Istanbul, Turkey.

Magd, H. and Curry, A. (2003). ISO 9000 and TQM: are they complementary or contradictory to each other? The TQM Magazine, 15(4), 244-256.

Manders, B., de Vries, H. J., \& Blind, K. (2016). ISO 9001 and product innovation: A literature review and research framework. Technovation, 48, 41-55

Mutinda, P. B. (2012). Challenges faced by organizations seeking ISO 9001 certification: a case of Kenya Medical Research Institute PhD), University of Nairobi, Kenya.

Pretesh, B. (2019). ISO 9001:2015 Clause 4 context of the organization. Retrieved on $20 / 04 / 2020$, from https://isoconsultantkuwait.com/2019/03/15/iso450012018-clause-4-context-of-the-organization/.

Robson, C., \& Mccartan, K. (2016). Real World Research (Fourth). Retrieved on 20/04/2020, from http://library1.nida.ac.th/termpaper6/sd/2554/1975 $\underline{5 . p d f}$

Rybski, C., Jochem, R., \& Homma, L. (2017). Empirical study on status of preparation for ISO 9001: 2015. Total Quality Management \& Business Excellence, 28(9-10), 1076-1089.Sampaio, P., Saraiva, P. and Guimarães Rodrigues, A. (2009), ISO 9001 certification research: questions, answers and approaches, International Journal of Quality \& Reliability Management, 26 (1), pp. 38-58.

Sari, Y., Wibisono, E., Wahyudi, R. D., \& Lio, Y. (2017, November). From ISO 9001: 2008 to ISO 9001: 2015: Significant changes and their impacts to aspiring organizations. Paper presented at IOP Conference Series: Materials Science and Engineering, UK.

Smith, P. R. (2018). Collecting sufficient evidence when conducting a case study. Qualitative Report, 23(5), 1043-1048.

Tarí, J. J., Molina-Azorín, J. F., \& Heras, I. (2012). Benefits of the ISO 9001 and ISO 14001 standards: A literature review. Journal of Industrial Engineering and Management (JIEM), 5(2), 297322.

Tomic, B., \& Spasojevic Brkic, V. K. (2019). Customer satisfaction and ISO 9001 improvement 
requirements in the supply chain. TQM Journal, 31(2), 222-238.

Tsim, Y. C., Yeung, V. W. S., \& Leung, E. T. c. (2002). An adaptation to ISO 9001:2000 for certified organisations. Managerial Auditing Journal, 17(5), 245-250.

Walaszczyk, A. (2018). Risk management of processes in the quality management system. Annales Universitatis Mariae Curie-Skłodowska, Sectio H Oeconomia, 52(1), 201-210
Wolniak, R. (2019). Support in ISO 9001: 2015. Zeszyty Naukowe. Organizacja $i$ Zarzadzanie/Politechnika Ślaska 137, 247- 261.

Woodside, A. G. (2010). Case study research: Theory Methods. Practice ( $1^{\text {st }}$ ed.) London: Emerald Group Publishing Ltd.

Yin, R. K. (2004). The case study anthology. Retrieved on 25/05/2019, from http://library1.nida.ac.th/termpaper6/sd/2554/1975 5.pdf. 